\title{
Editorial
}

\section{MARILISA BIRELLO}

UNIVERSITAT AUTÒNOMA DE BARCELONA

marilisa.birello@uab.cat

A quest volum monogràtic de CLIL Journal of Innovation and Research in Plurilingual and Pluricultural Education se centra en L'ensenyament del català com a llengua addicional a adults i tots els articles tenen un doble objectiu: crear punts de connexió entre docents, formadors i investigadors en adquisició i didàctica de la llengua i fer-ho aportant evidències sobre l'adquisició de la llengua $i$ experiències didàctiques en l'àmbit de l'ensenyament del català com a llengua addicional a adults.

El monogràfic conté sis articles, en què els autors aborden la complexitat i riquesa de l'ensenyament del català a persones adultes des de diferents vessants.

Llorenç Comajoan-Colomé ofereix un repàs de la relació complexa que existeix entre la recerca en l'ensenyament de les llengües addicionals a adults i les pràctiques docents.
Presenta els resultats d'un estudi sobre les percepcions dels docents de català com a llengua addicional sobre la influència de la recerca en les seves pràctiques docents. La meitat del professorat enquestat va declarar que les seves pràctiques havien rebut influència de la recerca en didàctica, especialment en relació amb aspectes metodològics de l'ensenyament de llengües.

Elga Cremades Cortiella analitza les característiques de la interllengua de l'alumnat de català com a llengua addicional que té com a llengua primera el serbi i l'anglès. L'anàlisi de les produccions escrites d'un corpus de 97 exàmens de nivell $\mathrm{B} 1$ de català mostra que el component ortogràfic, en el cas dels alumnes amb L1 anglès, i el component morfosintàctic, en el cas dels alumnes amb L1 serbi, presenten els percentatges més elevats d'errors. Els resultats també indiquen que les interferències de les llengües primeres i d'altres llengües 
del repertori lingüístic dels alumnes afecten sobretot el component lexicosemàntic.

Francesc Torres-Tamarit i Maria del Mar Vanrell presenten un estudi sobre com poden contribuir els universals lingüístics i la noció de marcatge tipològic a l'ensenyament i l'aprenentatge del sistema vocàlic i l'entonació del català com a llengua addicional. Posen de manifest les àrees que presenten més dificultats en l'aprenentatge i donen pistes sobre com tenir en compte els resultats de la recerca per a l'ensenyament, la programació i la creació de materials didàctics.

Maria Teresa Sans Bertran i Marilisa Birello se centren en la retroacció correctiva oral en alumnes adults poc escolaritzats en un centre de formació d'adults en seu penitenciària. Els resultats de l'estudi que presenten mostren que l'ús del castellà és molt comú a l'aula del centre penitenciari i que els errors més habituals són de pronunciació i lèxic. El tipus de retroacció correctiva oral més utilitzat per la docent són les reformulacions. D'altra banda, les traduccions al català dels enunciats en castellà dels alumnes és un tipus de retroacció molt emprat però poc efectiu. Els resultats mostren que la resposta dels alumnes porta a una reparació només en un terç dels casos, especialment després de les reformulacions i que les incitacions, com ara l'elicitació i la petició d'aclariment, tot i ser menys freqüents, porten a la reparació en un percentatge alt dels casos.

Albert Vilagrasa Grandia i Marilisa Birello expliquen una experiència didàctica basada en l'enfocament per tasques i duta a terme amb alumnes adults de català llengua addicional. A l'article presenten les fases de la unitat didàctica amb exemples de la interacció que té a l'aula durant les activitats de les diferents fases i destaquen la importància del text com a punt de partida que dona pas a activitats comunicatives i activitats de reflexió sobre la llengua, un contínuum que porta a l'execució de la tasca final. Els exemples aporten la realitat de l'aula i les converses que es generen entre alumnes i alumnes-docent i mostren com el treball amb un enfocament per tasques porta l'alumne a alternar l'ús de la llengua per comunicar amb l'atenció sobre la forma.

Finalment, a la secció A-B-C, Joana Álvarez, Laura Estors Sastre i Montserrat Pérez i Ventayol descriuen la tipologia d'alumnat que s'inscriu als cursos de català a les Escoles Oficials d'Idiomes i al Consorci per a la Normalització Lingüística. Expliquen les característiques dels alumnes entre elles: d'on venen els alumnes, les llengües que coneixen, les motivacions que els porten a fer els cursos de català. Fan també referència a les dificultats que troben els professors $i$ donen pistes per poder-les superar.

Vull expressar l'agraïment als autors que han fet possible aquest monogràfic. Vull agrair també als avaluadors anònims dels articles per la seva feina i per les valuoses aportacions que hi han fet. 